\title{
DINAMIKA MAKRO-MIKRO PADA PEMBIAYAAN MUSYARAKAH
}

\author{
Faizul Mubarok
}

Universitas Islam Negeri Syarif Hidayatullah Jakarta, Email : fayzmubarok@uinjkt.ac.id

\begin{abstract}
ABSTRAK
Tujuan penelitian ini adalah untuk mengetahui dinamika makro-mikro dan pengaruhnya pada pembiayaan musyarakah. Variabel bebas yang diujikan meliputi NPF, ROA, CAR, nilai tukar, inflasi, dan suku bunga, sedangkan variabel terikatnya adalah pembiayaan murabahah. Pengujian ini menguji pengaruh, baik secara simultan maupun secara parsial. Metode sampling yang digunakan adalah purposive sampling, yakni sampel yang digunakan dari populasi berdasarkan kriteria tertentu. Data yang digunakan pada penelitian ini adalah data sekunder bulanan dari tahun 2015 sampai dengan tahun 2017. Metode statistik yang digunakan adalah regresi linear berganda dengan melakukan uji asumsi klasik terlebih dahulu. Hasil penelitian menunjukkan bahwa variabel NPF, ROA, CAR, nilai tukar, inflasi, dan suku bunga secara bersama-sama berpengaruh signifikan terhadap pembiayaan musyarakah bank umum syariah. Secara parsial, variabel NPF, CAR, dan suku bunga secara signifikan berpengaruh terhadap pembiayaan musyarakah. Variabel ROA, nilai tukar, dan inflasi tidak berpengaruh terhadap pembiayaan musyarakah bank umum syariah.
\end{abstract}

Kata-Kata Kunci : Makro, Mikro dan Musyarakah

\begin{abstract}
The purpose of this study is to find out the macro-micro dynamics and their effects on musyarakah financing. The independent variables tested include NPF, ROA, CAR, exchange rate, inflation and interest rates, while the dependent variable is murabahah financing. This test tests the effect both simultaneously and partially. The sampling method used is purposive sampling, which is the sample used from the population based on certain criteria. The data used in this study is the monthly secondary data from 2015 until 2017. Statistical methods used are multiple linear regression by performing the classical assumption test first. The results showed that NPF, ROA, CAR, exchange rate, inflation and interest rate variables significantly influenced the musyarakah financing of sharia bank. While partially the NPF, CAR and interest rates variables significantly influence Musyarakah financing. While the ROA variable, the exchange rate and inflation do not affect the Islamic banks' musyarakah financing.
\end{abstract}

Keywords : Macro, Micro, Musyarakah 


\section{Islãmadîna \\ JURNAL PEMIKIRAN ISLAM}

\section{PENDAHULUAN}

Pada dasarnya masyarakat selalu membutuhkan modal finansial untuk memperluas usaha yang sudah dimiliki maupun membuka usaha baru disaat perekonomian sedang berkembang. Modal finansial tersebut, biasanya diperoleh pelaku usaha dari bank. Hal ini disebabkan karena akses terhadap perbankan relatif lebih mudah, mengingat jaringan kantor yang luas dan tersebar di berbagai daerah mulai dari perkotaan hingga pedesaan (Soekarni, 2011). Peranan bank masih dominan dalam memberikan kebutuhan dana bagi masyarakat dalam berbagai macam lapisan.

Tahun 1992 merupakan tahun dimana perbankan syariah hadir memberikan banyak variasi dalam skema pembiayaan. Fungsi perbankan syariah secara umum tidak terlalu berbeda dengan bank konvensional, terutama sama-sama sebagai lembaga intermediasi yang menghimpun dana dari masyarakat dan menyalurkan kembali dana tersebut kepada masyarakat yang memerlukannya dalam bentuk fasilitas pembiayaan (Djamil, 2014). Perbankan syariah sendiri memiliki karakteristik khusus yang tidak dimiliki oleh perbankan konvensional. Karakteristik perbankan syariah dapat sebagai mitra investasi, wakil, atau pemegang amanat dari pemilik dana atas investasi di sektor riil. Investasi tersebut difasilitasi dengan skema kemitraan (musyarakah) ataupun bagi hasil (mudharabah). Selanjutnya, Machmud (2010) menyatakan bahwa perbankan syariah juga memfasilitasi kegiatan distribusi melalui skema pembiayaan jual beli (murabahah) dan sewa menyewa (ijarah).

Sama halnya perbankan pada umumnya, bank syariah dalam menyalurkan pembiayaan juga mempertimbangkan faktor internal perbankan (mikro) dan eksternal perbankan (makro). Jika faktor internal perbankan dapat dikendalikan sepenuhnya oleh bank itu sendiri maka faktor eksternal tidak dapat dikendalikan oleh bank itu sendiri. Sehingga, hal yang perlu dilakukan oleh perbankan adalah mengambil suatu kebijakan untuk menyesuaikan dengan kondisi tersebut. Seperti halnya Muljono (2001) yang menyatakan bahwa bahwa besarnya kredit yang disalurkan kepada masyarakat dipengaruhi oleh faktor internal perbankan dan eksternal perbankan.

Perbankan sebagai lembaga keuangan yang memiliki banyak aktivitas, memiliki peluang yang sangat luas dalam memperoleh pendapatan. Untuk memperoleh pendapatan tersebut, perbankan selalu dihadapkan pada risiko. Risiko yang mungkin terjadi dapat menimbulkan kerugian bagi perbankan jika tidak dideteksi serta tidak dikelola sebagaimana mestinya (Idroes, 2011). Salah satu risiko yang sering dialami oleh perbankan adalah risiko kredit macet, yang tercermin dalam besarnya rasio pembiayaan bermasalah atau Non Performing Financing (NPF). Risiko ini, secara langsung memengaruhi pembiayaan yang akan diberikan perbankan syariah kepada masyarakat. Sehingga, semakin tinggi nilai Non Performing Financing (NPF) maka perbankan syariah akan menurunkan komposisi pembiayaan yang diberikan (Bakti, 2017). Selanjutnya, Return on Assets (ROA) sebagai indikator untuk profitabilitas suatu perbankan 
menjadi acuan dalam mengelola risiko, karena Bank Indonesia sebagai pengawas perbankan lebih mengutamakan nilai profitabilitas suatu bank (Dendawijaya, 2009). Begitu pula dengan indikator Capital Adequacy Rasio (CAR) yang merupakan rasio kecukupan modal, berkaitan dengan modal sendiri yang diperlukan untuk menutup risiko kerugian yang mungkin timbul dari pergerakan aktiva perbankan yang sebagian besar berasal dari dana pihak ketiga atau masyarakat (Dendawijaya, 2009).

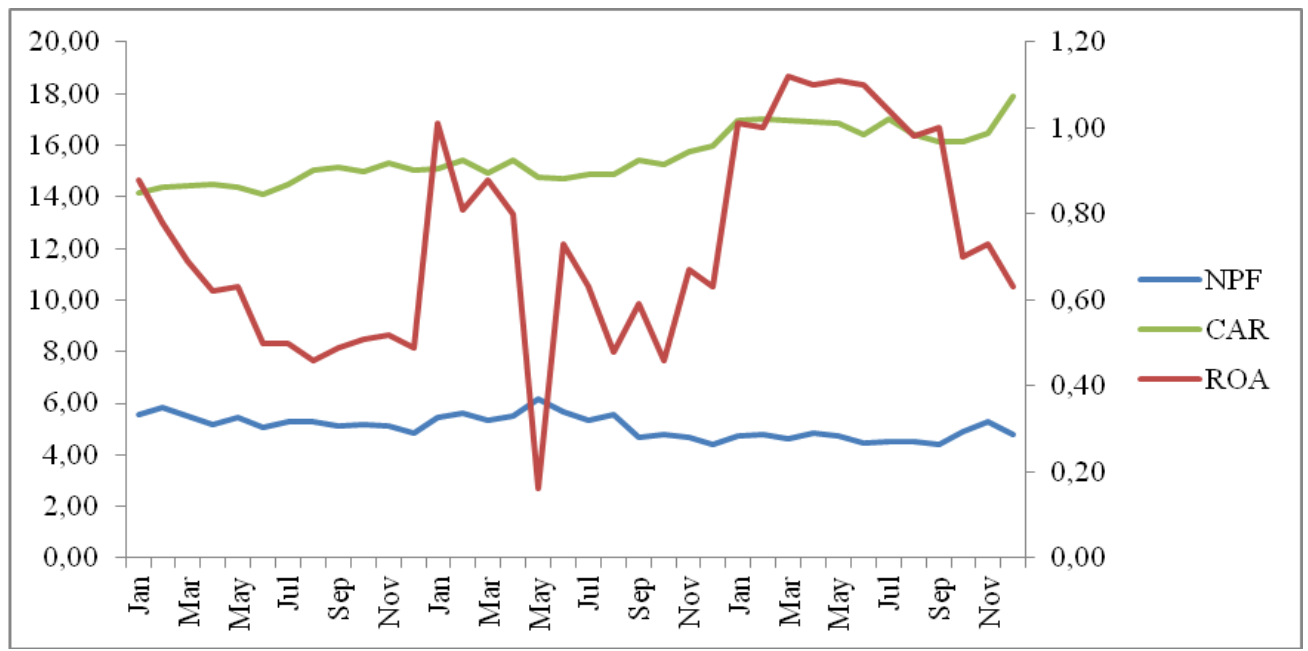

Gambar 1. Pergerakan NPF, CAR dan ROA Bank Umum Syariah 2015-2017 Sumber : Statistik Perbankan Syariah (2017)

Jika melihat dari pergerakan Non Performing Financing (NPF), Capital Adequacy Rasio (CAR), dan Return on Assets (ROA) bank umum syariah dari tahun 2015 sampai dengan 2017 mengalami pergerakan yang berfluktuatif. Pergerakan yang berfluktuatif ini mengakibatkan terganggunya pemberian pembiayaan. Indikator Non Performing Financing (NPF) memiliki rata-rata sebesar 5,09\% dan berada pada titik yang paling tinggi pada Mei 2016 sebesar 6,17\%, sedangkan titik yang paling rendah terjadi pada September 2017 sebesar 4,41\%. Indikator Capital Adequacy Rasio (CAR) memiliki rata-rata sebesar $0,73 \%$ dan berada pada titik yang paling tinggi pada Desember 2017 sebesar $17,91 \%$, sedangkan titik yang paling rendah terjadi pada Januari 2015 sebesar 14,16\%. Indikator Return on Assets (ROA) memiliki rata-rata sebesar 15,55\% dan berada pada titik yang paling tinggi pada Maret 2017 sebesar 1,12\%, sedangkan titik yang paling rendah terjadi pada Mei 2016 sebesar 0,16\%.

Dari sisi makro, indikator nilai tukar yang melonjak secara drastis dan tidak terkendali akan menyebabkan kesulitan dalam dunia usaha untuk menjalankan usahanya terutama yang menjual barangnya ke pasar ekspor atau menggunakan bahan baku dari luar negeri (Pohan, 2008). Indikator inflasi yang merupakan suatu peristiwa ekonomi yang hampir tidak pernah bisa dilepaskan dalam perekonomian. Inflasi adalah gejala kenaikan harga barang-barang yang bersifat umum dan berlangsung terus menerus (Raharja dan Manurung, 2004). 


\section{Islãmadîna \\ JURNAL PEMIKIRAN ISLAM}

Inflasi yang tinggi akan membuat perekonomian suatu negara akan sulit berkembang. Biaya yang terus menerus naik menyebabkan kegiatan yang produktif menjadi tidak menguntungkan. Selanjutnya, adanya risiko yang memungkinkan berpindahnya dana dari perbankan syariah ke perbankan konvensional dikarenakan adanya perbedaan rate keuntungan yang didapat ketika ada perubahan tingkat suku bunga. Sehingga, indikator tingkat suku bunga menjadi indikator yang perlu diperhatikan dalam melakukan pembiayaan.

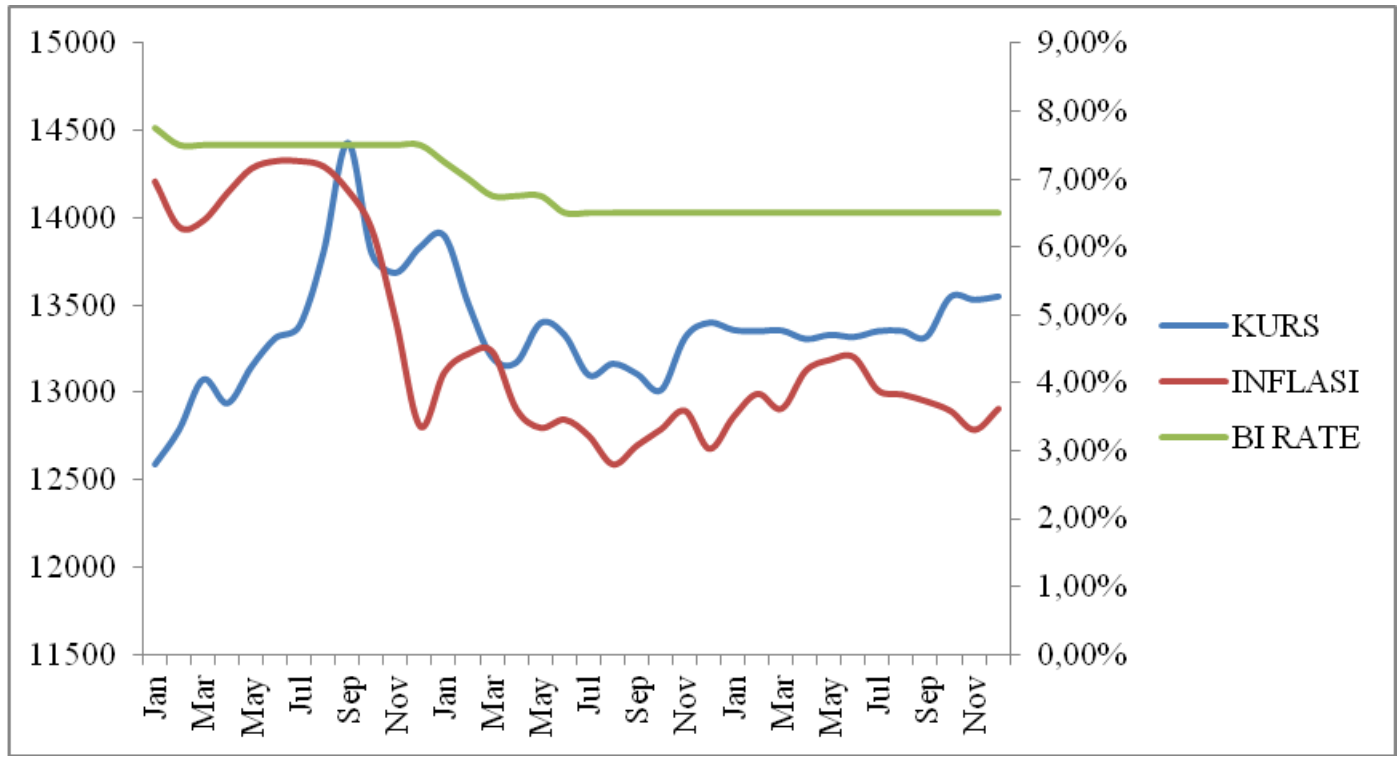

Gambar 2. Pergerakan Nilai Tukar, Inflasi dan Suku Bunga 2015-2017

Sumber : Statistik Perbankan Syariah (2017)

Gambar 2 menjelaskan mengenai pergerakan kondisi makroekonomi meliputi nilai tukar, inflasi, dan suku bunga. Terlihat dari pergerakan tersebut nilai tukar dan inflasi cenderung mengalami pergerakan yang berfluktuatif. Nilai tukar sepanjang pengamatan memiliki rata-rata dikisaran Rp. 13.360,dengan titik tertinggi berada pada September 2015 sebesar Rp. 14.430,- dan titik terendah berada pada Januari 2015 sebesar Rp. 12.584,--. Inflasi memiliki rata-rata $5 \%$ sepanjang pengamatan dengan titik tertinggi berada pada Mei Juni 2015 sejumlah 7,26\% dan titik terendah berada pada Desember 2016 sejumlah 3,02\%. Sedangkan tingkat suku bunga cenderung mengalami penurunan dan tetap dari pengamatan yang dilihat dari 7,75\% pada awal tahun 2015 menjadi 6,5\% pada akhir tahun 2017. 


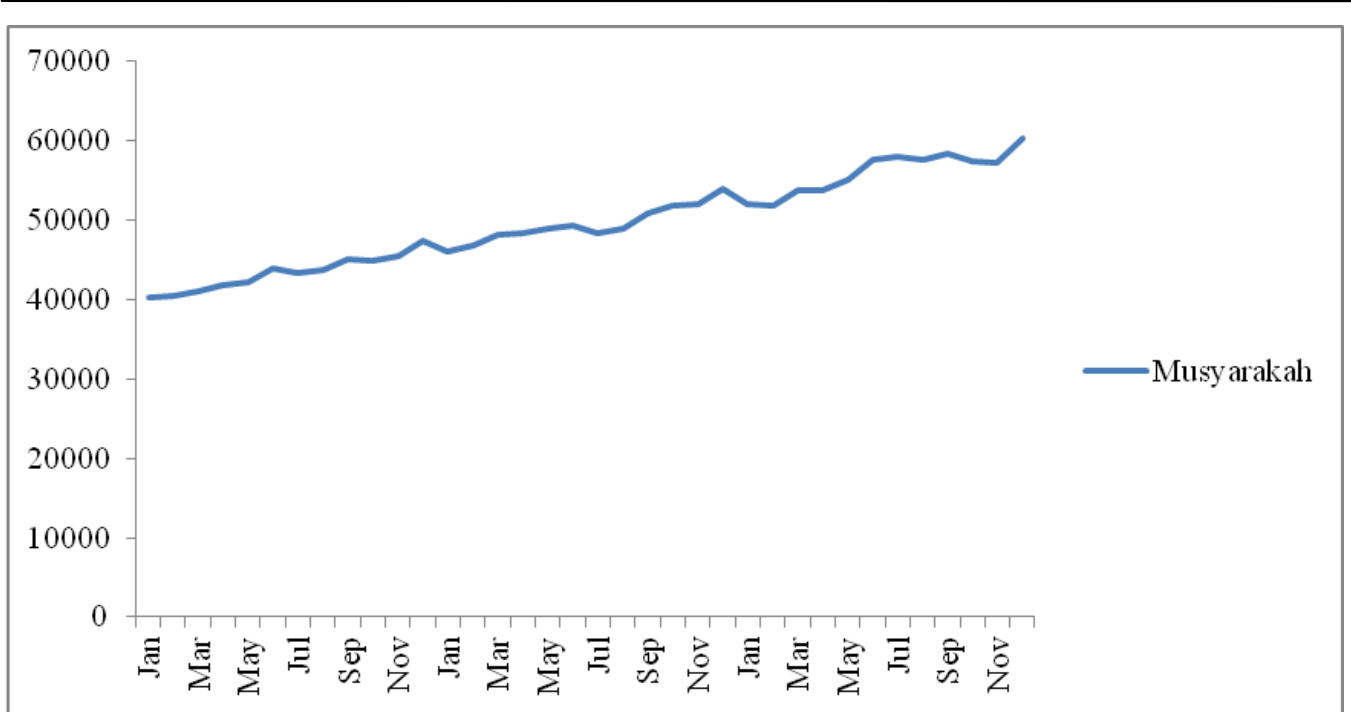

Gambar 3. Pergerakan Pembiayaan Musyarakah (dalam miliar) 2015-2017 Sumber : Statistik Perbankan Syariah (2017)

Jika dilihat dari gambar di atas, pembiayaan dengan menggunakan skema akad musyarakah sepanjang pengamatan cenderung mengalami kenaikan dari tahun ke tahun. Rata-rata pembiayaan dengan menggunakan skema akad musyarakah sepanjang pengamatan sekitar 49,658 triliun rupiah dengan titik tertinggi mencapai 60,409 triliun rupiah pada Desember 2017 dan titik terendah pada Januari 2015 sebesar 40,359 triliun rupiah. Karim (2008) menjelaskan bahwa penyaluran dana perbankan syariah kepada para nasabah, secara garis besar produk pembiayaan perbankan syariah terbagi ke dalam empat katagori yang dibedakan berdasarkan tujuan penggunannya, yaitu pertama, pembiayaannya dengan menggunakan prinsip jual-beli. Kedua, pembiayaannya dengan menggunakan prinsip sewa-menyewa. Ketiga, pembiayaannya dengan menggunakan prinsip bagi hasil. Keempat, pembiayaannya dengan menggunakan akad pelengkap. Dalam ruang lingkup perbankan, musyarakah merupakan penyatuan modal dari perbankan dan nasabah untuk kepentingan suatu usaha yang dilakukan bersama-sama. Musyarakah biasanya diaplikasikan untuk pembiayaan proyek, dimana nasabah dan pihak perbankan sama-sama menyediakan dana untuk membiayai proyek tersebut. Setelah proyek itu selesai, nasabah mengembalikan dana tersebut bersama dengan bagi hasil yang telah disepakati dalam perjanjian kontrak antar pihak (Djamil, 2014). Berdasarkan uraian yang telah dijelaskan di atas, maka penelitian ini bertujuan untuk mengetahui pengaruh makro-mikro terhadap pembiayaan musyarakah pada bank umum syariah di Indonesia.

\section{KAJIAN PUSTAKA}

Muhammad (2004) menyatakan bahwa pembiayaan merupakan fasilitas yang diberikan oleh bank syariah kepada masyarakat yang membutuhkan untuk menggunakan dana yang telah dikumpulkan oleh bank syariah dari masyarakat. 


\section{Islãmadîna \\ JURNAL PEMIKIRAN ISLAM}

Bentuk pembiayaan yang diberikan oleh bank syariah terdiri dari pembiayaan mudarabah, pembiayaan murabahah, pembiayaan musyarakah, pembiayaan salam, dan pembiayaan ijarah.

Musyarakah merupakan akad kerjasama antara dua pihak atau lebih untuk suatu usaha tertentu dimana masing-masing pihak memberikan kontribusi dana atau amal (expertise) dengan kesepakatan bahwa keuntungan dan risiko akan ditanggung bersama sesuai kesepakatan (Antonio, 2001). Biasanya pembiayaan yang menggunakan skema akad musyarakah adalah pembiayaan proyek, dimana nasabah dan bank bersama-sama menyediakan dana untuk membiayai proyek tersebut dan setelah proyek tersebut selesai, nasabah mengembalikan dana tersebut bersama dengan bagi hasil yang telah disepakati untuk bank. Selanjutnya pembiayaan menggunakan skema akad musyarakah adalah modal ventura dimana penanaman modal dilakukan untuk jangka waktu tertentu dan setelah itu bank melakukan divestasi atau menjual bagian sahamnya, baik secara langsung maupun bertahap.

Non performing financing (NPF) merupakan perbandingan antara pembiayaan yang bermasalah dengan total pembiayaan yang disalurkan oleh bank syariah. Antonio (2001) menjelaskan lebih lanjut bahwa pengendalian biaya mempunyai hubungan terhadap kinerja lembaga perbankan sehingga semakin kecil tingkat pembiayaan bermasalah maka akan semakin besar jumlah pembiayaan yang disalurkan oleh bank syariah, begitu pula sebaliknya.

Capital Adequacy Ratio (CAR) merupakan rasio kecukupan modal yang menunjukan kemampuan bank dalam mempertahankan modalnya serta kemampuan manajemen bank dalam mengidentifikasi, mengukur, mengawasi, dan mengontrol risiko-risiko yang timbul sehingga dapat memengaruhi besarnya modal bank (Kuncoro dan Suhardjono, 2011). Bank yang memiliki tingkat kecukupan modal yang baik menunjukkan indikator sebagai bank yang sehat.

Return On Assets (ROA) merupakan rasio yang menggambarkan kemampuan bank dalam mengelola dana yang diinvestasikan dalam keseluruhan aktiva sehingga menghasilkan keuntungan (Isna dan Sunaryo, 2012). Semakin tinggi ROA menunjukan semakin efisien operasional dari suatu perusahaan, begitu pula sebaliknya.

Inflasi merupakan meningkatnya harga-harga secara umum dan terus menerus. Kenaikan harga dari satu atau dua barang saja tidak dapat disebut inflasi, kecuali bila kenaikan itu meluas yang mengakibatkan kenaikan harga pada barang lainnya (Veratama, 2017). Inflasi dapat menimbulkan gangguan fungsi uang, melemahkan semangat menabung, meningkatkan kecenderungan untuk belanja, pengerukan tabungan dan penumpukan uang, permainan harga diatas standar kemampuan, penumpukan kekayaan dan investasi nonproduktif, serta distribusi barang relatif tidak stabil dan terkonsentrasi (Dournbus dan Fischer, 1992). 
Suku bunga merupakan biaya pinjaman atau harga yang dibayarkan untuk dana pinjaman tersebut yang biasanya dinyatakan dengan persentase (Mishkin, 2008). Suku bunga merupakan salah satu variabel dalam perekonomian yang senantiasa diamati secara cermat karena dampaknya yang begitu luas. Suku bunga dapat mempengaruhi secara langsung terhadap kesehatan perekonomian. Mengingat pengaruhnya yang begitu penting, maka akan mempengaruhi keputusan seseorang atau rumah tangga dalam mengkonsumsi, membeli rumah, membeli obligasi atau menaruhnya dalam rekening tabungan. Suku bunga juga mempengaruhi keputusan ekonomis bagi pengusaha atau pimpinan perusahaan apakah akan melakukan investasi pada proyek baru atau perluasan pasar (Puspopranoto, 2004).

Nilai tukar merupakan nilai tukar mata uang suatu negara terhadap mata uang negara lain. Mata uang sering digunakan sebagai alat pembayaran dan kesatuan hitung dalam transaksi transaksi dan keuangan internasional yang dikenal dengan istilah hard currency. Hard currency merupakan mata uang yang nilainya relatif stabil dan kadang-kadang mengalami apresiasi atau kenaikan nilai dibandingkan dengan mata uang lainnya (Mankiw, 2008).

\section{METODE PENELITIAN}

Data yang digunakan dalam penelitian ini seluruhnya menggunakan data sekunder bulanan dari awal tahun 2015 sampai dengan akhir tahun 2017, yang bersumber dari laporan statistik perbankan syariah, data nilai tukar, data inflasi dan data suku bunga dan diperoleh dari Otoritas Jasa Keuangan (OJK), pacific exchange rate service, Bank Indonesia (BI), Badan Pusat Statistik (BPS), serta studi kepustakaan yang berhubungan dengan penelitian ini.

Variabel yang digunakan dalam penelitian ini meliputi pembiayaan musyarakah, Non Performing Financing (NPF), Capital Adequacy Rasio (CAR), Return on Assets (ROA), nilai tukar, inflasi, dan tingkat suku bunga. Teknik pengambilan sampel yang digunakan adalah pengambilan sampel secara sengaja sesuai dengan kriteria yang dibutuhkan (purposive sampling). Karena penelitian ini bertujuan untuk melihat faktor-faktor apa saja yang memengaruhi pembiayaan musyarakah maka teknis analisis yang digunakan meliputi statistik deskriptif untuk mencari karakteristik masing-masing variabel, serta regresi linear berganda untuk pengujian pengaruh variabel bebas terhadap variabel terikat. Persamaan regresi linear berganda dapat dilihat pada persamaan di bawah ini.

$$
Y=\beta_{0}+\beta_{1} X_{1}+\beta_{2} X_{2}+\beta_{3} X_{3}+\beta_{3} X_{4}+\beta_{5} X_{5}+\beta_{6} X_{6}+e
$$

Keterangan

$\begin{array}{clcl}\mathrm{Y} & \text { : Pembiayaan Musyarakah } & \mathrm{X}_{5} & \text { : Inflasi } \\ \mathrm{X}_{1} & \text { : Net Performing Finance (NPF) } & \mathrm{X}_{6} & \text { : Suku Bunga (RATE) } \\ \mathrm{X}_{2} & \text { : Capital Adequacy Rasio (CAR) } & \beta_{0} & : \text { Konstanta } \\ \mathrm{X}_{3} & \text { : Return On Asset (ROA) } & \beta_{1} \ldots \mathrm{B}_{6} & : \text { Koefisien regresi } \\ \mathrm{X}_{4} & \text { : Nilai Tukar (KURS) } & e & : \text { Error }\end{array}$




\section{Islãmadîna \\ JURNAL PEMIKIRAN ISLAM}

Volume 19, No. 2, September 2018 : 59-74

\section{HASIL DAN PEMBAHASAN}

Sebelum dilakukan pengujian variabel, dilakukan pemeriksaan terhadap asumsi-asumsi yang harus dilalui dan harus memenuhi semua asumsi, meliputi data yang diteliti harus terdistribusi normal, tidak adanya masalah heteroskedastisitas pada data yang diteliti dan tidak ada masalah autokorelasi pada data yang diteliti. Dari hasil pengujian normalitas data menggunakan pendekatan pengujian Kolgomorov-Smirnov memperoleh hasil dengan nilai 0,897 dimana nilai tersebut lebih besar dari 0,05 (5\%) yang merupakan batas toleransinya sehingga dapat disimpulkan bahwa data penelitian tersebut sudah terdistribusi normal.

Selanjutnya, hasil pengujian heteroskedastisitas dengan pendekatan pengujian glejser menunjukkan bahwa semua variabel yang diujikan memperoleh hasil dengan nilai sign. (Tabel 1) lebih besar dari 0,05 (5\%) yang merupakan batas toleransinya, sehingga dapat disimpulkan bahwa data sudah terbebas dari masalah heteroskedastisitas. Dan terakhir, pengujian agar terbebas dari autokorelasi menggunakan pendekatan pengujian Durbin Watson yang diperoleh hasil dengan nilai sebesar 1,624. Nilai tersebut berada diantara nilai dari tabel Durbin Watson $\mathrm{d}_{\mathrm{L}}=1.1144$ dan $\mathrm{d}_{\mathrm{U}}=1.8764$ sehingga berdasarkan hasil pengujian tersebut dengan membandingkan nilai perhitungan Durbin Watson dengan tabel Durbin Watson dapat disimpulkan bahwa data tersebut sudah terbebas dari masalah autokorelasi.

Tabel 1. Hasil Pengujian Normalitas, Heteroskedastisitas dan Autokorelasi

\begin{tabular}{|c|c|c|c|}
\hline \multicolumn{2}{|c|}{$\begin{array}{c}\text { One-Sample Kolmogorov-Smirnov } \\
\text { Test }\end{array}$} & \multicolumn{2}{|c|}{ Model Summary } \\
\hline $\begin{array}{l}\text { Asymp. Sig. } \\
\text { (2-tailed) }\end{array}$ & .897 & Durbin-Watson & 1.624 \\
\hline \multicolumn{4}{|c|}{ Coefficients } \\
\hline \multicolumn{2}{|c|}{ Model } & \multicolumn{2}{|c|}{ Sig. } \\
\hline \multicolumn{2}{|c|}{ (Constant) } & \multicolumn{2}{|c|}{.925} \\
\hline \multicolumn{2}{|c|}{ NPF } & \multicolumn{2}{|c|}{.249} \\
\hline \multicolumn{2}{|c|}{$\mathrm{ROA}$} & \multicolumn{2}{|c|}{.695} \\
\hline \multicolumn{2}{|c|}{ CAR } & \multicolumn{2}{|c|}{.230} \\
\hline \multicolumn{2}{|c|}{ KURS } & \multicolumn{2}{|c|}{.767} \\
\hline \multicolumn{2}{|c|}{ INFLASI } & \multicolumn{2}{|c|}{.903} \\
\hline \multicolumn{2}{|c|}{ RATE } & \multicolumn{2}{|c|}{.782} \\
\hline
\end{tabular}

Nilai R Square merupakan besaran yang memberikan informasi goodness of fit dari persamaan, yaitu memberikan proporsi atau persentase kekuatan pengaruh variabel independen (Non Performing Financing, Return on Assets, Capital Adequacy Rasio, nilai tukar, inflasi dan tingkat suku bunga) secara 
simultan terhadap variasi dari variabel dependen (pembiayaan musyarakah). Koefisien determinasi (R Square) digunakan untuk mengukur seberapa jauh kemampuan model dalam menerangkan variasi variabel dependennya.

Hasil pengolahan pada penelitian ini, menjelaskan bahwa hasil dari model tersebut memiliki nilai $\mathrm{R}$ Square sebesar 92,2\% yang artinya bahwa variabel-variabel independen dapat menjelaskan pengaruhnya terhadap pembiayaan musyarakah, sedangkan sisanya sebesar 7,8\% dijelaskan oleh faktor-faktor lainnya yang tidak dimasukkan ke dalam penelitian.

Tabel 2. Hasil Uji R Square

\begin{tabular}{|c|c|r|r|r|}
\hline \multicolumn{5}{|c|}{ Model Summary $^{\mathbf{b}}$} \\
\hline Model & R & R Square & Adjusted R Square & Std. Error of the Estimate \\
\hline 1 & $.960^{\mathrm{a}}$ & .922 & .905 & .03601 \\
\hline
\end{tabular}

a. Predictors: (Constant), RATE, KURS, ROA, NPF, INFLASI, CAR; b. Dependent Variable: MUS

Pengujian terhadap koefisien regresi secara simultan dilakukan dengan uji F. Pengujian ini dilakukan untuk mengetahui pengaruh semua variabel independen yang terdapat di dalam model secara bersama-sama (simultan) terhadap variabel dependennya. Hasil pengolahan data penelitian didapatkan dengan melihat nilai sign. sebesar .0000 yang berarti nilai tersebut lebih kecil dari nilai $\alpha$ sebesar 5\%. Dari hasil ini mengindikasikan bahwa secara keseluruhan semua variabel independen secara bersama-sama memiliki pengaruh terhadap variabel dependennya.

Tabel 3. Hasil Uji Secara Simultan (Uji F)

\begin{tabular}{|l|l|r|r|r|r|r|}
\hline \multicolumn{2}{|c|}{ Model } & \multicolumn{1}{|c|}{ ANOVA $^{\mathrm{b}}$} \\
\hline \multirow{3}{*}{1} & $\begin{array}{c}\text { Sum of } \\
\text { Squares }\end{array}$ & \multicolumn{1}{c|}{$\mathrm{df}$} & $\begin{array}{c}\text { Mean } \\
\text { Square }\end{array}$ & F & Sig. \\
\hline \multirow{2}{*}{1} & Regression & .442 & 6 & .074 & 56.775 & $.000^{\mathrm{a}}$ \\
\cline { 2 - 7 } & Residual & .038 & 29 & .001 & & \\
\cline { 2 - 7 } & Total & .479 & 35 & & & \\
\hline
\end{tabular}

a. Predictors: (Constant), RATE, KURS, ROA, NPF, INFLASI, CAR

b. Dependent Variable: MUS

Pengujian terhadap koefisien regeresi secara parsial dilakukan dengan uji t. Pengujian ini dilakukan untuk mengetahui signifikansi peran secara parsial antara variabel independen terhadap variabel dependen dengan mengasumsikan bahwa variabel independen lain dianggap konstan. Variabel Non Performing Financing (NPF), Capital Adequacy Rasio (CAR) dan RATE memiliki nilai kurang dari 5 persen dengan tingkat signifikansi sebesar 95\%, sedangkan Return on Assets (ROA), KURS dan inflasi memiliki nilai lebih dari 5\% dengan tingkat signifikansi sebesar 95\%. Sehingga variabel Non Performing Financing (NPF), Capital Adequacy Rasio (CAR) dan tingkat suku bunga (RATE) memiliki pengaruh secara signifikan terhadap permbiayaan musyarakah, sedangkan variabel Return on Assets (ROA), nilai tukar (KURS) dan inflasi tidak memiliki pengaruh. Persamaan model regresi selengkapnya dari penelitian 


\section{Islãmadîna \\ JURNAL PEMIKIRAN ISLAM}

ini dapat dilihat dari persamaan di bawah ini.

$$
\mathrm{Y}=2,001-0,275 \mathrm{X}_{1}-0,021 \mathrm{X}_{2}+0,581 \mathrm{X}_{3}+0,528 \mathrm{X}_{4}-0,007 \mathrm{X}_{5}-0,976 \mathrm{X}_{6}+e
$$

\begin{tabular}{clcl}
\multicolumn{4}{c}{ Keterangan } \\
$\mathrm{Y}$ & : Pembiayaan Musyarakah & $\mathrm{X}_{4}$ & : Nilai Tukar (KURS) \\
$\mathrm{X}_{1}$ & : Net Performing Finance (NPF) & $\mathrm{X}_{5}$ & : Inflasi \\
$\mathrm{X}_{2}$ & : Capital Adequacy Rasio (CAR) & $\mathrm{X}_{6}$ & : Suku Bunga (RATE) \\
$\mathrm{X}_{3}$ & : Return On Asset (ROA) & $e$ & $:$ Error
\end{tabular}

\section{Interpretasi Hasil}

Pengaruh Non Performing Financing (NPF) terhadap pembiayaan musyarakah. Variabel NPF memiliki probabilitas 0,01 lebih kecil dari $\alpha$ sebesar 5\% serta koefisien -0,275. Hasil ini menunjukkan bahwa variabel Non Performing Financing (NPF) secara signifikan berpengaruh negatif terhadap pembiayaan musyarakah. Artinya jika nilai Non Performing Financing (NPF) mengalami kenaikan maka kemungkinan bank syariah akan lebih berhati-hati dengan mengurangi pembiayaan dengan skema akad musyarakah begitu pula sebaliknya.

Hasil ini sejalan dengan penelitian yang dilakukan oleh Bakti (2017) yang menyatakan bahwa Non Performing Financing (NPF) secara signifikan berpengaruh negatif terhadap pembiayaan pada 11 bank umum syariah di Indonesia. Begitu pula dengan penelitian yang dilakukan oleh Mizan (2017) yang menyatakan bahwa Non Performing Financing (NPF) secara signifikan berpengaruh terhadap pembiayaan murabahah. Penelitian tersebut menguji indikator, seperti pengaruh Dana Pihak Ketiga (DPK), Capital Adequacy Ratio (CAR), Non Performing Financing (NPF), Debt to Equity Ratio (DER) dan Return On Assets (ROA) terhadap pembiayaan murabahah pada bank umum syariah di Indonesia dengan menggunakan pendekatan analisis regresi linear berganda. Dengan begitu, hasil secara parsial dari penelitian tersebut diperoleh bahwa indikator Dana Pihak Ketiga (DPK) dan Non Performing Financing (NPF) berpengaruh signifikan terhadap penyaluran pembiayaan murabahah pada bank umum syariah di Indonesia, sebaliknya indikator Capital Adequacy Rasio (CAR), Return On Assets (ROA), Debt to Equity Rasio (DER) tidak berpengaruh terhadap pembiayaan murabahah pada bank umum syariah di Indonesia.

Penelitian selanjutnya yang dilakukan oleh Wardiantika dan Kusumaningtias (2013) yang menyatakan bahwa signifikan berpengaruh terhadap pembiayaan murabahah. Penelitian tersebut menguji indikator, seperti Dana Pihak Ketiga (DPK), Capital Adequacy Ratio (CAR), Non Performing Financing (NPF) dan Sertifikat Wadiah Bank Indonesia (SWBI) terhadap pembiayaan murabahah pada bank umum syariah di Indonesia dengan menggunakan pendekatan analisis regresi linear berganda. Sehingga hasil secara parsial dari penelitian tersebut diperoleh bahwa indikator Dana Pihak 
Ketiga (DPK) dan Non Performing Financing (NPF) berpengaruh signifikan terhadap pembiayaan murabahah pada bank umum syariah di Indonesia, sebaliknya indikator Capital Adequacy Ratio (CAR) dan Sertifikat Wadiah Bank Indonesia (SWBI) tidak berpengaruh terhadap pembiayaan murabahah pada bank umum syariah di Indonesia.

Pengaruh ROA terhadap pembiayaan musyarakah. Variabel Return on Assets (ROA) memiliki probabilitas 0,327 lebih besar dari a sebesar 5\% serta koefisien -0,021. Hasil ini menunjukan bahwa variabel Return on Assets (ROA) tidak memiliki pengaruh terhadap pembiayaan musyarakah. Hasil ini sejalan dengan penelitian yang dilakukan oleh Anwar dan Miqdad (2017) yang menyatakan bahwa Return on Assets (ROA) tidak memiliki pengaruh terhadap pembiayaan mudarabah. Penelitian tersebut menguji indikator, seperti Dana Pihak Ketiga (DPK), Capital Adequacy Ratio (CAR), Return On Asset (ROA) terhadap pembiayaan mudarabah pada bank umum syariah di Indonesia dengan menggunakan pendekatan analisis regresi linear berganda. Sehingga hasil secara parsial dari penelitan tersebut diperoleh bahwa indikator Dana Pihak Ketiga (DPK) berpengaruh signifikan terhadap pembiayaan mudarabah pada bank umum syariah di Indonesia, sebaliknya indikator Capital Adequacy Ratio (CAR), Return On Asset (ROA) tidak berpengaruh terhadap pembiayaan mudarabah pada bank umum syariah di Indonesia.

Karena itu, hasil ini berbeda dengan penelitian yang dilakukan oleh Nahrawi (2017) yang menyatakan bahwa Return on Assets (ROA) secara signifikan berpengaruh negatif terhadap pembiayaan murabahah pada BNI syariah. Penelitian tersebut menguji indikator, seperti Capital Adequacy Ratio (CAR), Return On Assets (ROA) dan Non Performing Financing (NPF) terhadap pembiayaan murabahah pada Bank Negara Indonesia (BNI) Syariah dengan menggunakan pendekatan analisis regresi linear berganda. Sehingga hasil secara parsial dari penelitian tersebut diperoleh bahwa semua indikator yang diujikan, meliputi Capital Adequacy Ratio (CAR), Return on Assets (ROA) dan Non Performing Financing (NPF) berpengaruh signifikan terhadap pembiayaan murabahah pada Bank Negara Indonesia (BNI) Syariah.

Tabel 3. Hasil Uji Secara Parsial (Uji t)

\begin{tabular}{|c|c|c|c|c|c|c|}
\hline \multicolumn{7}{|c|}{ Coefficients $^{\mathrm{a}}$} \\
\hline \multirow{2}{*}{\multicolumn{2}{|c|}{ Model }} & \multicolumn{2}{|c|}{$\begin{array}{l}\text { Unstandardized } \\
\text { Coefficients }\end{array}$} & \multirow{2}{*}{$\begin{array}{c}\text { Standardized } \\
\text { Coefficients } \\
\text { Beta }\end{array}$} & \multirow[t]{2}{*}{$\mathrm{t}$} & \multirow[t]{2}{*}{ Sig. } \\
\hline & & B & Std. Error & & & \\
\hline \multirow[t]{6}{*}{1} & (Constant) & 2.001 & 2.938 & & .681 & .501 \\
\hline & NPF & -.275 & .100 & -.204 & -2.746 & .010 \\
\hline & ROA & -.021 & .021 & -.069 & -.997 & .327 \\
\hline & CAR & .581 & .200 & .317 & 2.906 & .007 \\
\hline & KURS & .528 & .306 & .112 & 1.723 & .096 \\
\hline & INFLASI & -.007 & .041 & -.019 & -.182 & .857 \\
\hline
\end{tabular}




\section{Islãmadîna \\ JURNAL PEMIKIRAN ISLAM}

Volume 19, No. 2, September $2018: 59-74$

\begin{tabular}{|c|l|l|l|l|l|l|}
\hline & RATE & -.976 & .233 & -.567 & -4.199 & .000 \\
\hline a. Dependent Variable: MUS
\end{tabular}

Pengaruh Capital Adequacy Rasio (CAR) terhadap pembiayaan musyarakah. Variabel Capital Adequacy Rasio (CAR) memiliki probabilitas 0,007 lebih kecil dari a sebesar 5\% serta koefisien 0,581. Hasil ini menunjukkan bahwa variabel Capital Adequacy Rasio (CAR) secara signifikan berpengaruh positif terhadap pembiayaan musyarakah. Jika nilai Capital Adequacy Rasio (CAR) mengalami kenaikan, maka kemungkinan bank syariah akan lebih meningkatkan pembiayaan dengan akad musyarakah begitu pula sebaliknya.

Hasil ini sejalan dengan penelitian yang dilakukan oleh Mili et al. (2017) yang menyatakan bahwa Capital Adequacy Rasio (CAR) memiliki pengaruh pada perbankan di negara berkembang dan maju. Sampel yang digunakan pada penelitian tersebut terdiri dari 310 anak perusahaan dari 123 bank multinasional. Selanjutnya dipilih menjadi 180 beroperasi pada negara maju dan 130 pada negara berkembang yang data tersebut bersumber dari International Monetary Fund (IMF). Lebih lanjut Allen et al. (2014) mengemukakan bahwa penyaluran pinjaman dapat memberikan dampak negatif dari kerentanan bank induk pada anak perusahaannya terlebih pinjaman bank asing ditentukan oleh berbagai faktor di negara berkembang dan di negara-negara maju.

Pengaruh nilai tukar (KURS) terhadap pembiayaan musyarakah. Variabel nilai tukar (KURS) memiliki probabilitas 0,096 lebih besar dari $\alpha$ sebesar 5\% serta koefisien 0,528. Hasil ini menunjukkan bahwa variabel KURS secara tidak berpengaruh terhadap pembiayaan musyarakah. Jika nilai tukar mengalami apresiasi maka kemungkinan bank syariah akan lebih meningkatkan pembiayaan dengan akad musyarakah begitu pula sebaliknya. Hasil ini sejalan dengan penelitian yang dilakukan oleh Rifai et al. (2017) yang menyatakan bahwa nilai tukar tidak berpengaruh terhadap total pembiayaaan perbankan syariah di Indonesia.

Penelitian tersebut menguji indikator, seperti nilai tukar rupiah, laju Inflasi, jumlah uang beredar dan pertumbuhan ekspor terhadap total pembiayaan perbankan syariah dengan Dana Pihak Ketiga (DPK) sebagai variabel moderating dengan menggunakan pendekatan analisis regresi linear berganda. Sehingga hasil secara parsial dari penelitan tersebut diperoleh bahwa indikator laju inflasi dan jumlah uang beredar berpengaruh signifikan terhadap pembiayaan pada bank umum syariah di Indonesia, sebaliknya indikator nilai tukar dan pertumbuhan ekspor tidak berpengaruh terhadap pembiayaan pada bank umum syariah di Indonesia.

Hasil tersebut berbeda dengan hasil yang diperoleh dari penelitian Veratama (2017) yang menyatakan bahwa nilai tukar secara signifikan berpengaruh negatif terhadap tingkat pengguliran dana pada bank umum devisa syariah. Penelitian tersebut menguji indikator, seperti nilai tukar, inflasi, Dana Pihak Ketiga (DPK), Sertifikat Wadiah Bank Indonesia (SWBI) dan pendapatan 
bank terhadap tingkat pengguliran dana bank syariah dengan menggunakan pendekatan analisis regresi linear berganda. Sehingga hasil secara parsial dari penelitan tersebut diperoleh bahwa indikator nilai tukar dan Dana Pihak Ketiga (DPK) berpengaruh signifikan terhadap tingkat pengguliran dana bank syariah di Indonesia, sebaliknya inflasi dan Sertifikat Wadiah Bank Indonesia (SWBI) tidak berpengaruh terhadap tingkat pengguliran dana bank syariah di Indonesia.

Pengaruh inflasi terhadap pembiayaan musyarakah. Variabel INFLASI memiliki probabilitas 0,857 lebih besar dari $\alpha$ sebesar $5 \%$ serta koefisien $-0,007$. Hasil ini menunjukkan bahwa variabel INFLASI tidak memiliki pengaruh terhadap pembiayaan musyarakah. Hasil ini sejalan dengan penelitian yang dilakukan oleh Saekhu (2015) yang menyatakan bahwa inflasi tidak berpengaruh terhadap pembiayaan yang dijelaskan kemudian bahwa bank syariah tidak memakai mekanisme suku bunga. Sehingga tingkat bagi hasil atau marjin laba produk bank syariah tidak harus menyesuaikan dengan tingkat inflasi, seperti layaknya suku bunga bank konvesional.

Penelitian tersebut menguji indikator inflasi terhadap kinerja pembiayaan bank syariah, volume pasar uang antar bank syariah dan posisi outstanding Sertifikat Wadiah Bank Indonesia (SWBI) dengan menggunakan pendekatan analisis Vector Autoregression (VAR). Begitu pula dengan penelitian yang dilakukan oleh Mahfudz (2016) yang menyatakan bahwa inflasi tidak berpengaruh terhadap pembiayaan pada bank umum syariah di Indonesia. Penelitian tersebut menguji indikator, seperti Dana Pihak Ketiga (DPK), Financing to Deposit Ratio (FDR), Return On Asset (ROA), Non Performing Financing (NPF), inflasi dan tingkat suku bunga terhadap pembiayaan pada bank umum syariah di Indonesia dengan menggunakan pendekatan analisis regresi linear berganda. Sehingga hasil secara parsial dari penelitan tersebut diperoleh bahwa indikator Dana Pihak Ketiga (DPK), Financing to Deposit Ratio (FDR), Return On Asset (ROA), Non Performing Financing (NPF) dan tingkat suku bunga berpengaruh signifikan terhadap pembiayaan pada bank umum syariah di Indonesia, sebaliknya indikator inflasi tidak berpengaruh terhadap pembiayaan pada bank umum syariah di Indonesia.

Pengaruh tingkat suku bunga (RATE) terhadap pembiayaan musyarakah. Variabel tingkat suku bunga memiliki probabilitas 0,000 lebih kecil dari $\alpha$ sebesar 5\% serta koefisien -0,976. Hasil ini menunjukkan bahwa variabel RATE secara signifikan berpengaruh negatif terhadap pembiayaan musyarakah. Jika RATE mengalami kenaikan, maka kemungkinan bank syariah akan lebih berhati-hati dengan mengurangi pembiayaan dengan akad musyarakah begitu pula sebaliknya.

Perpindahan dana dari bank syariah ke bank konvensional dalam jangka pendek akan memengaruhi likuiditas perbankan syariah karena jika bunga perbankan meningkat maka nasabah lebih memilih untuk menyimpan dananya di perbankan konvensional daripada dalam perbankan syariah, sebaliknya jika nilai bunga perbankan mengalami penurunan maka nasabah akan lebih memilih 


\section{Islãmadîna \\ JURNAL PEMIKIRAN ISLAM}

perbankan syariah untuk menyimpan dana dari pada perbankan konvensional (Widiyanto dan Diani, 2015).

Hasil penelitian ini juga sejalan dengan penelitian yang dilakukan oleh Wicaksono (2015) dengan menggunakan metode Unit Root Test, Cointegration Analysis, Impulse Response Function (IRF) dan Variance Decomposition (VDC). Hasil dari penelitian tersebut menunjukkan bahwa perubahan suku bunga kredit bank konvensional memiliki pengaruh terhadap nilai equivalent rate pembiayaan murabahah di Bank Islam, meskipun perubahan tersebut tidak secara signifikan mempengaruhi jumlah total pembiayaan murabahah. Perubahan jumlah total pembiayaan lebih dipengaruhi oleh pergerakan tingkat suku bunga yang ditetapkan oleh Bank Indonesia (BI rate).

\section{SIMPULAN}

Penelitian ini bertujuan untuk menganalisa faktor-faktor yang mempengaruhi pembiayaan musyarakah pada bank umum syariah di Indonesia. Variabel bebas yang diujikan meliputi Non Performing Financing (NPF), Return on Assets (ROA), Capital Adequacy Rasio (CAR), nilai tukar, inflasi dan suku bunga, sedangkan variabel terikatnya adalah pembiayaan musyarakah dengan menggunakan pendekatan analisis regresi linear berganda.

Berdasarkan hasil pengujian secara bersama-sama (simultan) menggunakan uji $\mathrm{F}$ dapat disimpulkan bahwa semua variabel bebas meliputi Non Performing Financing (NPF), Return on Assets (ROA), Capital Adequacy Rasio (CAR), nilai tukar, inflasi dan suku bunga secara signifikan berpengaruh terhadap pembiayaan bank umum syariah. Berdasarkan hasil pengujian secara parsial menggunakan uji dapat disimpulkan bahwa Non Performing Financing (NPF) secara signifikan berpengaruh negatif terhadap pembiayaan musyarakah, Capital Adequacy Rasio (CAR) secara signifikan berpengaruh positif terhadap pembiayaan musyarakah dan suku bunga secara signifikan berpengaruh negatif terhadap pembiayaan musyarakah. Sedangkan Return on Assets (ROA), nilai tukar dan inflasi masing-masing tidak memiliki pengaruh terhadap pembiayaan musyarakah.

\section{DAFTAR PUSTAKA}

Allen, F., Hryckiewicz, A., Kowalewski O., \& Tumer-Alkan G. (2014). Transmission of Bank Liquidity Shocks in Loan and Deposit Markets: The Role of Interbank Borrowing and Market Monitoring. Journal of Financial Stability, 15 : 112-126.

Antonio, M, S. (2001). Bank Syariah Dari Teori ke Praktik. Jakarta: Gema Insani.

Anwar, C. \& Miqdad, M. (2017). Pengaruh

Dana Pihak Ketiga (DPK), Capital Adequacy Ratio (CAR), Return On Asset (ROA) Terhadap Pembiayaan Mudarabah Pada Bank Umum Syariah Tahun 2008 - 2012. Riset dan Jurnal Akuntansi, 1(1): 42-47. 
Bakti, N. S. (2017). Analisis DPK, CAR, ROA dan NPF terhadap Pembiayaan pada Perbankan Syarih. Jurnal Bisnis dan Manajemen, 17(2), 15-28.

Dendawijaya, L. (2009). Manajemen Perbankan. Bogor: Ghalia Indonesia.

Djamil, F. (2014). Penyelesaian Pembiayaan Bermasalah Di Bank Syariah. Jakarta: Sinar Grafika.

Dornbusch, R., \& Fischer, S. (1992). Makroekonomi. Jakarta: Erlangga.

Idroes, F. N. (2011). Manajemen Risiko Perbankan. Jakarta: PT. Raja Grafindo Persada.

Isna K, A., \& Sunaryo, K. 2012. Analisis Pengaruh Return On Assets, BOPO, dan Suku Bunga terhadap Tingkat Bagi Hasil Deposito Mudharabah pada Bank Umum Syariah. Jurnal Ekonomi dan Bisnis, 11(1): 29-42.

Karim, A. (2008). Bank Islam Analisis Fiqih dan Keuangan. Jakarta: Raja Grafindo Persada.

Kuncoro, M., \& Suhardjono. 2011. Manajemen Perbankan: Teori dan Aplikasi. Yogyakarta: BPFE.

Machmud, A. \& Rukmana. (2010). Bank Syariah: Teori, Kebijakan, dan Studi Empiris di Indonesia. Jakarta: Erlangga.

Mahfudz, I, N. (2016). Analisis Faktor-faktor yang Mempengaruhi Pembiayaan Pada Bank Umum Syariah (Studi Pada Bank Umum Syariah Tahun 2012-2015). Jurnal Manajemen, 5(3): 1-14.

Mili, M., Sahut, J, M., Trimeche, H., \& Teulon, F. (2017). Determinants of the Capital Adequacy Ratio of Foreign banks' Subsidiaries: The Role of Interbank Market and Regulation. Journal Research in International Business and Finance, 42: 442-453.

Mishkin, F. (2008). Ekonomi Uang, Perbankan dan Pasar Keuangan, Ed ke-8. Jakarta: Salemba Empat.

Mizan. (2017). DPK, CAR, NPF, DER dan ROA Terhadap Pembiayaan Murabahah pada Bank Umum Syariah. Jurnal Balance, 14(1): 72-83.

Muhammad. (2004). Teknik Perhitungan Bagi Hasil dan Profit Margin pada Bank Syariah. Yogyakarta: UII Press.

Muljono, T, P. (2001). Manajemen Perkreditan Bagi Bank Komersiil. Yogyakarta: BPFE.

Nahrawi, A, A. (2017). Pengaruh Capital Adequacy Ratio (CAR), Return On Assets (ROA) dan Non Performing Financing (NPF) Terhadap Pembiayaan Murabahah BNI Syariah. Jurnal Perisai, 1(2): 141-179.

Pohan, A. (2008). Potret Kebijakan Moneter Indonesia. Jakarta: PT Raja Grafindo Persada. 


\section{Islãmadîna \\ JURNAL PEMIKIRAN ISLAM}

Raharja, P. \& Manurung, M. (2004). Pengantar Makro Ekonomi. Jakarta: LPPE-UI.

Rifai, S, A., Susanti, H., \& Setyaningrum, A. (2017). Analisis Pengaruh Kurs Rupiah, Laju Inflasi, Jumlah Uang Beredar dan Pertumbuhan Ekspor terhadap Total Pembiayaan Perbankan Syariah dengan Dana Pihak Ketiga sebagai Variabel Moderating. Jurnal Muqtasid, 8(1): 18-39.

Saekhu. (2015). Pengaruh Inflasi terhadap Kinerja Pembiayaan Bank Syariah, Volume Pasar Uang antar Bank Syariah dan Posisi Outstanding Sertifikat Wadiah Bank Indonesia. Jurnal Economica, 6(1): 103-128.

Puspopranoto, S. (2004). Keuangan Perbankan dan Pasar Keuangan (Konsep, Teori dan Realita). Jakarta: Pustaka LP3ES.

Soekarni, M. (2011). Dinamika Pembiayaan Perbankan Syariah dalam Mengembangkan Dunia Usaha. Jurnal Ekonomi dan Pembangunan, 22(1), 83-95.

Veratama, Y. (2017). Pengaruh Kurs, Inflasi, DPK, SWBI dan Pendapatan Bank terhadap Tingkat Pengguliran Dana Bank Syariah. Jurnal Penelitian Ekonomi dan Bisnis, 1-17.

Wardiantika, L. \& Kusumaningtias, R. (2014). Pengaruh DPK, CAR, NPF dan SWBI Terhadap Pembiayaan Murabahah pada Bank Umum Syariah tahun 2008-2012. Jurnal Ilmu Manajemen, 2(4): 1550-1561.

Wicaksono, R, A. (2015). Pengaruh Perubahan Tingkat Suku Bunga Kredit Bank Konvensional dan Tingkat Suku Bunga Bank Indonesia terhadap Pembiayaan Bank Islam berbasis Murabahah. Jurnal Aplikasi Manajemen, 13(3): 494-501.

Widiyanto, E. \& Diyani, L, A. (2015). Analisis Pengaruh Tingkat Suku Bunga BI Terhadap Pembiayaan Mudharabah. Jurnal Bisnis dan Komunikasi, 2(1): 98-108. 